\title{
Carnet de Voyage en Irlande
}

\section{Flora Aurima-Devatine}

Ireland

Homeland

Home

Land

I feel at home

In Ireland

To Elizabeth

My great-grandmother

From my hotel room

By the window to the land

I crossed

Your father's land

Your father's country

Your father's homeland

And I felt at home

In your father's homeland

In your father's homeland

And I thought a lot

I thought strongly

I thought deeply

I thought carefully 
I thought of you

I thought landly

Homelandly

I thought a lot

Because I missed you

To Julia

My great-great-grandmother

From my hotel room

By the window to the land

I caught your force

I caught your will

I caught and I understood your nature

I imagined your smile

I imagined your face smiling

I imagined your eyes shining, twinkling

I caught and I imagined a lot

Because I needed you

To Francis

My great-great-grandfather

I saw the descendants of your fellows

I searched your 'dark hair'

I searched your 'blue eyes'

And I found them in our car driver

From Castlewellan to Leitrim

From Leitrim to Legannany

From Leitrim to Castlewellan

From Castlewellan to Newcastle

From a top of the road of Leitrim to Castlewellan I saw the point of view to the sea of Newcastle And I thought of you of your dreams Full of travels by boat by sea full of new countries Full of a best future full of us your descendants And I understood you because I felt the same feelings For all my children and for all of my grandchildren 
I tried your Guiness

I drunk in memory of you

Don't be cross with me

I prefer our Hinano beer!

I talked and talked a lot

I thought of you

And I felt happy

Because I admired you

I understood the travels I did

I understood the countries I crossed

I understood the ways I went by

The oceans I passed across

The people I met

It was a never-ending road

An uncompleted way

To you to me to us

It was a boundless, an untiring

A long way to your land

To my ancestor's land

I felt a lot of the past

The travels I had to do

The fields I had to cross

The oceans, to navigate

The roads, to follow

The feelings, to experience

I understood

I believe I understood

I think I believe I understood

I hope I wish to understand

I want to live

I would like to be

I need it

I need so

I need so much. 
TOURING PACIFIC CULTURES

I needed to see and feel

The Mountains of Mourne

I saw and I felt the land all

The land of my ancestors

I can't say it's enough

Just it's an appreciated part of me

I feel nostalgic about this part of me

But I'm lucky to have had a touch of it

To have had a breeze of it

To have had a sweet smell of it

I feel happy and a little bit on my hunger

To you all

My ancestors

I couldn't express my love

Because I didn't feel it

I didn't know you

But all my thoughts, my spirit,

All my words about you

Only express this tender thing, the feeling

That I love you all.

«- Pourquoi aller voir à quoi ressemble le pays des ancêtres?

- Quitte à voir, à visiter un pays étranger, autant aller voir aussi celui de ses ancêtres !»

Traduction (2010-2011) de Jean Anderson

Directrice du New Zealand Centre for Literary Translation à

l'Université Victoria de Wellington 
This text is taken from Touring Pacific Cultures, edited by Kalissa Alexeyeff and John Taylor, published 2016 by ANU Press, The Australian National University, Canberra, Australia. 